\title{
Evaluation of nutritive value, phytochemical screening, total phenolic content and in-vitro antioxidant activity of the seed of Prunus domestica L.
}

\author{
Rishi Kumar Shukla ${ }^{1}$, Kishan $^{1^{*}}$, Abha Shukla ${ }^{2} \&$ Rahul Singh $^{3}$ \\ ${ }^{1}$ Department of Chemistry, Gurukula Kangri (Deemed to be University), Haridwar 249 404, Uttarakhand, India \\ ${ }^{2}$ Department of Chemistry, Kanya Gurukula Campus, Gurukula Kangri (Deemed to be University), Haridwar 249404, Uttarakhand, India \\ ${ }^{3}$ Department of Pharmaceutical Sciences, Gurukula Kangri (Deemed to be University), Haridwar 249 404, Uttarakhand, India \\ *Email: prajapati75kishan@gmail.com
}

\section{ARTICLE HISTORY}

Received: 25 April 2021

Accepted: 14 July 2021

Available online: 21 August 2021

\section{KEYWORDS}

Prunus domestica

Proximate analysis

Nutritive value

Total phenolic

Antioxidant activity

\begin{abstract}
Prunus domestica L. is a member of the Rosaceae family that shows many biological activities including antioxidant, antimicrobial, antihaemolytic, anti-inflammatory, hepatoprotective activity and many other activities. In the current study, we evaluated nutritive value, phytochemical screening, total phenolic content and antioxidant activity by DPPH and FRAP method for the different extracts obtained by successive soxhlet extraction using the different solvents based on their polarity. Results show that it is a good source of energy. Phytochemical screening revealed the presence of many secondary metabolites which include alkaloids, carbohydrates, glycosides, protein, steroids and terpenoids, fixed oils and fat as well as phenolic compounds. The highest total phenolic content was found in the ethyl acetate fraction. Highest antioxidant activity by DPPH method is reported in ethyl acetate fraction (IC50 $=1837.399 \pm 0.377 \mu \mathrm{g} / \mathrm{ml}$ ) while the ferric reducing antioxidant power was maximum for diethyl ether $(56.032 \pm 0.985 \mu \mathrm{M} / \mathrm{ml}$ FRAP value $=0.325 \pm 0.002)$.
\end{abstract}

\section{Introduction}

Various fruits constitute an important part of the human diet. It is accepted worldwide that a diet enriched with fruits and vegetables lowers the hazard of persistent sicknesses like cardiovascular diseases, cancer and leading a long and healthy life (1). These food products have been regarded as nutraceuticals or functional foods. The foods which are a good source of antioxidants (like phenolic acids, flavonoids etc.) have high demand in today's market as a nutraceutical. Fruits are the source of low fat and low calories while dried fruits have high protein contents, high mineral contents (2).

Prunus domestica L. of the family Rosaceae is generally regarded as plum $(2,3)$. The family Rosaceae is the $19^{\text {th }}$ largest family of plants (4) and includes about 3000 species whereas the genus Prunus includes about 400-430 species; but only 89 are enlisted in the Genetic Resources Information System. In India, about 36 species of Prunus have been reported of which 18 species can be used for the cultivation of different purposes (5-9).

It is used in combination with other drugs to treat leucorrhoea, irregular menstrual and miscarriage followed by debility (10). Plums and prunes show laxative stomachic effect. The bark of $P$. domestica is used as febrifuge while roots are utilized as astringent (11). P. domestica is the source of calcium, magnesium, vitamin A, potassium and fibre (12). This species possesses a discrete place in the Indian medicinal system due to its numerous health benefits (2). It is abundant in different bioactive phytochemicals such as anthocyanins, pectins and carotenoids, lignans, abscisic acid, glucoside, flavonoids, flavonoids glycosides, bipyrrole, dihydroflavonols and carbohydrates (12-19). These bioactive compounds are found to be varied in concentration depending upon various pre-harvesting factors (20). Plums are an excellent source of nutrients with a significant contribution to human nutrition. Due to many important phytochemicals, this fruit has an effective antioxidant activity (21). In addition to this, different extracts of $P$. domestica show many important activities namely antibacterial, anticancer, antihyperlipidemic, blood pressure-lowering activity, anxiolytic activity and antidiabetic activity $(2,22,23)$.

The fruit of the $P$. domestica is juicy and fleshy which is eaten while the seed is usually discarded. Therefore, the current study aims to evaluate the

C Shukla et al (2021). This is an open-access article distributed under the terms of the Creative Commons Attribution License, which permits unrestricted use, distribution and reproduction in any medium, provided the original author and source are credited (https://creativecommons.org/licenses/by/4.0/). 
nutritive value, qualitative phytochemical screening and antioxidant activity of the seed (i.e., kernel) of $P$. domestica.

\section{Materials and Methods}

\section{Reagents and Chemicals}

Petroleum ether (SD fine), methanol (Merck), diethyl ether (SD fine), ethyl acetate (Merck), double distilled water, folin's reagent (Merck), sodium hydroxide (Fisher), sodium acetate trihydrate (Merck), nitric acid (Fisher), gallic acid (Merck), sodium carbonate monohydrate (Merck), sulphuric acid (Fisher), 2,2diphenyl-1-picrylhydrazyl (DPPH) (Alpha acer), ascorbic acid (Merck) and 2,4,6-tris-(2-pyridyl)-striazine (TPTZ) (SRL chem). All other reagents which were used in this study were of analytical grade.

\section{Sample collection}

For the collection of the seeds, plums were purchased from the local garden situated in Haridwar, Uttarakhand. Seeds were dried under the shade. The plant was recognized and confirmed by the Botanical Survey of India (BSI), Dehradun under accession number 374. For the authentication of the plant material two herbarium specimens were prepared, one of which is deposited in the Botanical Survey of India.

\section{Physical Parameters and Proximate Analysis}

Evaluation of the physical parameters and proximate analysis for the calculation of the nutritive value was done according to the Indian pharmacopeia and earlier study on Bombax ceiba $(24,25)$.

\section{Preparation of Extracts}

Soxhlet extractor was employed for the extraction. Briefly, 200 gms of the powdered plant material was put in the thimble of the soxhlet extractor. Extraction was done using the solvents petroleum ether, diethyl ether, ethyl acetate, methanol and double-distilled water in the increasing order of the polarity. Approximately 72 cycles of siphoning were conducted for each solvent or the extraction was continued till the siphoning tube appears colourless. After the extraction, the extracts of different solvents were concentrated under reduced pressure using the rotary evaporator and stored in a refrigerator for further examination.

\section{Phytochemical Screening}

Phytochemical screening of the different extracts for the presence of the various phytoconstituents was carried out by standard qualitative methods $(26,27)$. Each concentrate was screened for the nearness of natural dynamic mixes like alkaloids, sugars, glycosides, amino acids, proteins, triterpenoids and steroids, flavonoids, phenolics, gums. Furthermore mucilages, naphthoquinones and so forth.

\section{Total Phenolic Content}

The folin-ciocalteau method was adopted for the determination of the total phenolic content of each extract with some modifications. Briefly, $100 \mu \mathrm{l}$ extract dilution at a concentration $(1000 \mu \mathrm{g} / \mathrm{ml})$ or gallic acid (10-400 $\mu \mathrm{g} / \mathrm{ml})$ put in a test tube, containing $7.9 \mathrm{ml}$ of the distilled water. Distilled water also serves as blank. Now, added $500 \mu \mathrm{l}$ of the folin's reagent to the volumetric flask and shaken properly and incubated for $8 \mathrm{~min}$ at room temperature. Now, $1.5 \mathrm{ml}$ of $20 \% \mathrm{Na}_{2} \mathrm{CO}_{3}$ was added to the above mixture to make the final volume $10 \mathrm{ml}$ and incubated for 2 hrs at room temperature. Absorbance was measure at $765 \mathrm{~nm}$ with UV-Vis double beam spectrophotometer (Systronics 2205). Calculations were carried out using the calibration curve of gallic acid. The total phenolic content of each extract was expressed as mg of gallic acid equivalents (GAE) per gms dried weight (mg GAE/g dw) (28).

\section{Antioxidant Activity}

\section{DPPH Free Radical Scavenging Assay}

All the obtained extracts of the seed of the $P$. domestica were evaluated for their antioxidant power by the DPPH method according to standard methodology with some modification (29). Briefly, 1 $\mathrm{ml}$ of the extract $(100-5000 \mu \mathrm{g} / \mathrm{ml})$ was mixed with $0.004 \%$ DPPH solution and leave at room temperature for $1 \mathrm{hr}$. After $1 \mathrm{hr}$ absorbance was measured at 517 nm using the Systronics 2205 double beam UV-Visible spectrophotometer. The change in the color from pink to yellow is directly proportional to the scavenging of the DPPH radical. Ascorbic acid was used as standard. $1 \mathrm{ml}$ of the solvent and $3 \mathrm{ml}$ of the DPPH solution serve as blank.

$$
\begin{gathered}
\text { \% Inhibition }= \\
\frac{\text { Absorbace of Blank }- \text { Absorbance of sample }}{\text { Absorbance of Blank }} \times \mathbf{1 0 0}
\end{gathered}
$$

\section{Ferric Reducing Antioxidant Power (FRAP Assay)}

FRAP assay was carried out according to standard methodology with some modification (30). Stock solution include $300 \mathrm{mM}$ acetate buffer ( $\mathrm{pH} 3.6), 40$ $\mathrm{mM} \mathrm{HCl}$ solution, $20 \mathrm{mM} \mathrm{FeCl} 3.6 \mathrm{H}_{2} \mathrm{O}$ (Ferric chloride hexahydrate) solution, $10 \mathrm{mM}$ TPTZ (2,4,6-tri-(2pyridyl)-1,3,5-triazine) solution. Working FRAP reagent was prepared by mixing Acetate buffer, ferric chloride hexahydrate solution and TPTZ solution in the 10:1:1 ratio. Antioxidant potential was evaluated by reacting $1 \mathrm{ml}$ of extract $(500 \mu \mathrm{g} / \mathrm{ml})$ and $10 \mathrm{ml}$ of working FRAP reagent. The absorbance of the coloured product was taken at $593 \mathrm{~nm}$ after incubating at $37{ }^{\circ} \mathrm{C}$ after $30 \mathrm{~min} .1 \mathrm{ml}$ methanol and $10 \mathrm{ml}$ working FRAP reagent act as the control. Ascorbic acid was used as standard.

\section{Results and Discussion}

\section{Physical Parameters and Proximate Analysis}

Table 1 and 2, show the results of the physical parameters and proximate analysis respectively. The study revealed total ash $4.115 \pm 0.118 \%$, acid insoluble ash $1.032 \pm 0.072 \%$, water-soluble ash $1.296 \pm 0.049 \%$ and sulphated ash $4.020 \pm 0.075 \%$. While water-soluble and alcohol soluble extractive values are found to be $26.746 \pm 1.265 \%$ and $26.759 \pm 0.983 \%$ which show that extraction with water and alcohol is approximately equally exhaustive. Proximate analysis, revealing the 
moisture content $10.553 \pm 0.132 \%$, total nitrogen content $3.133 \pm 0.036 \%$, protein $19.580 \pm 0.227 \%$, crude fat $22.441 \pm 0.087 \%$, crude fibre $27.870 \pm 0.440 \%$, total carbohydrates $\quad 43.292 \pm 0.035 \%, \quad$ available carbohydrates $15.422 \pm 0.419 \%$. Different ash values measure the presence of substances like silica, silicates, oxalates, carbonates, phosphates, oxides and volatile inorganic substances indicative of the richness of the mineral contents in the particular plant part. Plum seeds are a good source of protein, carbohydrates, fat as well as fibre, which constitutes the major essential for the living being. On the basis of the above values, the nutritive value of the seed was calculated and its nutritive value is found to be $341.991 \pm 2.106 \mathrm{Kcal} / 100 \mathrm{gm}$. High nutritive value is

Table 1. Physical evaluation of the seed of $P$. domestica

\begin{tabular}{ll}
\hline Parameter & Value (\%) \\
\hline Total ash & $4.115 \pm 0.118$ \\
\hline Acid insoluble ash & $1.032 \pm 0.072$ \\
\hline Water-soluble ash & $1.296 \pm 0.049$ \\
\hline Sulphated ash & $4.020 \pm 0.075$ \\
\hline Water-soluble extractive value & $26.746 \pm 1.265$ \\
\hline Alcohol soluble extractive value & $26.759 \pm 0.983$ \\
\hline $\begin{array}{l}\text { Each experiment was performed in triplicate. All the values are } \\
\text { represented as the mean } \pm \text { SD. }\end{array}$
\end{tabular}

Table 2. Proximate analysis of the seed of $P$. domestica

\begin{tabular}{lc}
\hline Parameter & Value (\%) \\
\hline Moisture Contents or Loss on Drying & $10.553 \pm 0.132$ \\
\hline Total Nitrogen Contents & $3.133 \pm 0.036$ \\
\hline Protein & $19.580 \pm 0.227$ \\
\hline Crude Fat & $22.441 \pm 0.087$ \\
\hline Crude Fibre & $27.870 \pm 0.440$ \\
\hline Total Carbohydrate Contents & $43.292 \pm 0.035$ \\
\hline Available Carbohydrate Contents & $15.422 \pm 0.419$
\end{tabular}

Nutritive Value (Energy value) 341.991 $\pm 2.106 \mathrm{Kcal} / 100 \mathrm{gm}$ Each experiment was performed in triplicate. All the values are represented as the mean $\pm \mathrm{SD}$.

suggestive that plum seed can be the source of the feed and fodder.

\section{Extractive Yield}

Table 3, displays the yield of the extract of different solvents based on the total material. Petroleum ether,

Table 3. Extractive yield of the extract obtained by successive sohxlet extraction using the different solvents

\begin{tabular}{lc}
\hline Solvent & Yield (\%) \\
\hline Petroleum ether & 13.752 \\
\hline Diethyl ether & 10.045 \\
\hline Ethyl acetate & 7.251 \\
\hline Methanol & 11.934 \\
\hline Aqueous & 14.625 \\
\hline
\end{tabular}

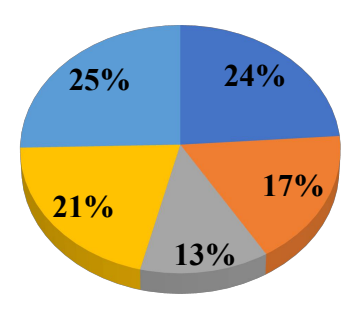

$$
\begin{aligned}
& \square \text { Petroleum ether } \quad \text { Diethyl ether } \square \text { Ethyl acetate } \\
& \text { Methanol } \quad \text { Aqueous }
\end{aligned}
$$

Fig. 1. \% yield of the different extracts concerning the total extract. diethyl ether, ethyl acetate, methanol and water yield $13.752 \%$, $10.045 \%, 7.251 \%, 11.934 \%$ and $14.625 \%$ respectively concerning the total material. Fig. 1, represents the yield of the different obtained extracts based on total extract.

\section{Phytochemical Screening}

Table 4, representing the results of the qualitative phytochemical screening. Phytochemical screening has shown the presence of carbohydrates, glycosides, protein, steroids and terpenoids, fixed oil and fats, flavonoids and phenolic compounds. Bioactivity and the therapeutic value of the plant extract are attributed to the phytoconstituents of the plant extract.

\section{Total Phenolic Content}

Table 5, emphasizes the total phenolic content of the different fractions and found to be in the order ethyl acetate > methanol > water> diethyl ether > petroleum ether in an amount of 28.366 $\pm 0.577>$ $27.700 \pm 1.000>23.366 \pm 1.154>19.366 \pm 0.577>$ $10.033 \pm 0.577$. All the total phenolic contents are expressed in terms of mgGAE.gm-1dw. For the calculation of the total phenolic content calibration curve of gallic acid was also prepared with equation $y=0.001 x+0.0013, R^{2}=0.9992$.

\section{Antioxidant Activity \\ DPPH Free Radical Scavenging Assay}

Table 6, depicts the results of the $\mathrm{DPPH}$ free radical scavenging assay. The IC50 (concentration of the plant extract required to scavenge the $50 \%$ of DPPH concentration) values of diethyl ether, ethyl acetate, methanol and aqueous fractions are 3730.567 \pm 0.914 $\mu \mathrm{g} / \mathrm{ml}, 1837.399 \pm 0.377 \mu \mathrm{g} / \mathrm{ml}, 2520.596 \pm 0.398 \mu \mathrm{g} / \mathrm{ml}$, $3490.380 \pm 0.777 \mu \mathrm{g} / \mathrm{ml}$ respectively whereas the IC50 value of the petroleum ether fraction was beyond our dilutions prepared and IC50 value of ascorbic acid was determined in the same way as that of the sample and it is found to be $13.296 \pm 0.075 \mu \mathrm{g} / \mathrm{ml}$. Fig. 2 , shows the variation of the percentage inhibition against the concentration of the plant extract and standard.

\section{Ferric Reducing Antioxidant Power (FRAP Assay)}

Table 7, representing the results of the FRAP method. Fig. 3, shows the comparison among the FRAP values of the different fractions. Fig. 4, shows the standard calibration curve of the ascorbic acid giving the equation $y=0.0041 x+0.0996, R^{2}=0.9915$ and the results are expressed in $\mu \mathrm{M} / \mathrm{ml}$. Diethyl ether has the highest ferric reducing antioxidant power $56.032 \pm 0.985 \mu \mathrm{M} / \mathrm{ml}$, followed by petroleum ether $20.341 \pm 0.645 \mu \mathrm{M} / \mathrm{ml}$, ethyl acetate $18.634 \pm 0.243$ $\mu \mathrm{M} / \mathrm{ml}$, methanol $15.788 \pm 0.745 \mu \mathrm{M} / \mathrm{ml}$ and aqueous $14.731 \pm 0.879 \mu \mathrm{M} / \mathrm{ml}$. The FRAP value of the standard ascorbic acid is found to be $472.601 \pm 0.140 \mu \mathrm{M} / \mathrm{ml}$.

\section{Conclusion}

Various experiments conducted on the seed of this plant revealed it to be an excellent source of energy because of its excellent nutritional value. Phytochemical screening shows the presence of many 
Table 4. Qualitative phytochemical screening of the $P$. domestica seed extracts

\begin{tabular}{|c|c|c|c|c|c|c|c|}
\hline & \multirow{2}{*}{\multicolumn{2}{|c|}{ Phytoconstituents and Test Performed }} & \multicolumn{5}{|c|}{ Extract } \\
\hline & & & $\mathbf{P E}$ & DEE & EA & MeOH & $\mathrm{H}_{2} \mathrm{O}$ \\
\hline \multirow{3}{*}{ Alkaloids } & Mayer's Test & & - & - & - & - & + \\
\hline & Wagner's Test & & - & - & - & - & + \\
\hline & Hager's Test & & - & - & - & - & - \\
\hline \multirow{4}{*}{ Carbohydrates } & Molisch’s Test & & - & + & + & + & + \\
\hline & Fehling’s Test & & - & + & + & + & + \\
\hline & Benedict's Test & & - & - & + & + & - \\
\hline & Seliwanoff's Test & & - & - & + & + & - \\
\hline \multirow{7}{*}{ Glycosides } & \multirow{2}{*}{ Anthraquinone Glycosides } & Bontrager's Test & - & - & - & - & - \\
\hline & & Test for Hydroxy-anthraquinones & - & - & - & - & - \\
\hline & \multirow{3}{*}{ Cardiac Glycosides } & Keller-Killiani Test & + & + & + & + & + \\
\hline & & Legal's Test & - & - & - & - & - \\
\hline & & Baljet's Test & - & - & - & - & - \\
\hline & Saponin Glycosides & Froth Formation Test & - & - & - & + & + \\
\hline & Flavanol Glycosides & $\mathrm{Mg}$ and $\mathrm{HCl}$ Reduction & - & - & - & - & - \\
\hline \multirow{3}{*}{ Protein } & Heat Test & & - & - & - & - & - \\
\hline & Biuret Test & & - & - & - & - & + \\
\hline & Xanthoproteic Test & & + & + & + & + & + \\
\hline Amino Acid & Ninhydrin Test & & - & - & - & - & - \\
\hline Steroids and Terpenoids & Salkowski Test & & + & + & - & + & - \\
\hline Fixed Oils and Fats & Spot Test & & + & + & + & + & - \\
\hline \multirow{2}{*}{ Flavonoids } & Shinoda Test & & - & - & - & - & - \\
\hline & Zn-HCl Test & & - & - & - & - & - \\
\hline \multirow{4}{*}{$\begin{array}{l}\text { Phenolic Compounds and } \\
\text { Tannins }\end{array}$} & Lead Acetate Test & & - & - & - & + & + \\
\hline & Ferric Chloride Test & & - & - & - & - & - \\
\hline & Test for Catechin & & - & - & - & - & - \\
\hline & Test for Chlorogenic acid & & - & - & - & - & - \\
\hline Gums and Mucilage & & & - & - & - & - & - \\
\hline \multirow{2}{*}{ Naphthoquinone } & Juglone Test & & - & - & - & - & - \\
\hline & Dam-Karrer Test & & - & - & - & - & \\
\hline
\end{tabular}

Where, $\mathrm{PE}=$ Petroleum ether, $\mathrm{DEE}=$ Diethyl ether, $\mathrm{EA}=$ Ethyl acetate, $\mathrm{MeOH}=$ Methanol $\quad$ and $\mathrm{H}_{2} \mathrm{O}=$ Water. Where: $(+\mathrm{ve})=$ present and $(-\mathrm{ve})=$ absent.

secondary metabolites. The total phenolic content and the antioxidant study revealed that the seed of the $P$. domestica has antioxidant potential. Total phenolic content in plant extract is responsible for its various biological activities including antioxidant activity. We have found a strong correlation between the total phenolic content and the antioxidant activity by the DPPH method. The antioxidant potential is attributed to phenolic content, plays an important role in drug development and supplements, which could be very important in preventing or decreasing the rate of oxidative stress.

Table 5. Total phenolic content of the different seed extracts of $P$. domestica

\begin{tabular}{lc}
\hline Solvent /extract & $\begin{array}{c}\text { Total phenolic content } \\
\text { (mgGAE.gm-1dw) }\end{array}$ \\
\hline Petroleum ether & $10.033 \pm 0.577$ \\
\hline Diethyl ether & $19.366 \pm 0.577$ \\
\hline Ethyl acetate & $28.366 \pm 0.577$ \\
\hline Methanol & $27.700 \pm 1.000$ \\
\hline Aqueous & $23.366 \pm 1.154$ \\
\hline
\end{tabular}

Each experiment was performed in triplicate. All the values are represented as the mean $\pm \mathrm{SD}$.

Table 6. DPPH free radical scavenging assay of the different seed extracts of $P$. domestica and ascorbic acid (standard)

\begin{tabular}{lc}
\hline Solvent/extract & IC50 $(\boldsymbol{\mu g} / \mathbf{m l})$ \\
\hline Ascorbic acid (standard) & $13.296 \pm 0.075$ \\
\hline Petroleum ether & Beyond the Dilution \\
\hline Diethyl Ether & $3730.567 \pm 0.914$ \\
\hline Ethyl acetate & $1837.399 \pm 0.377$ \\
\hline Methanol & $2520.596 \pm 0.398$ \\
\hline Aqueous & $3490.380 \pm 0.777$ \\
\hline
\end{tabular}

Each experiment was performed in triplicate. All the values are represented as the mean \pm SD.

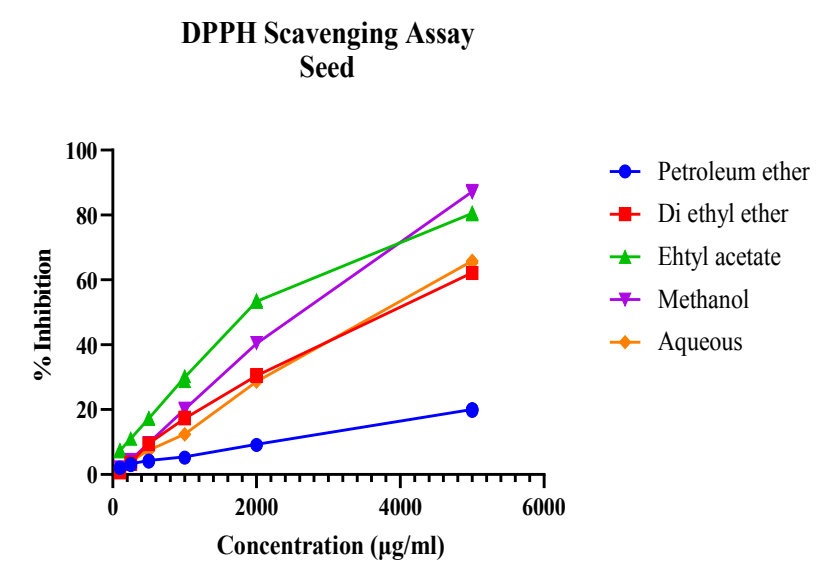

DPPH Scavenging Assay

Ascorbic Acid

(Standard)

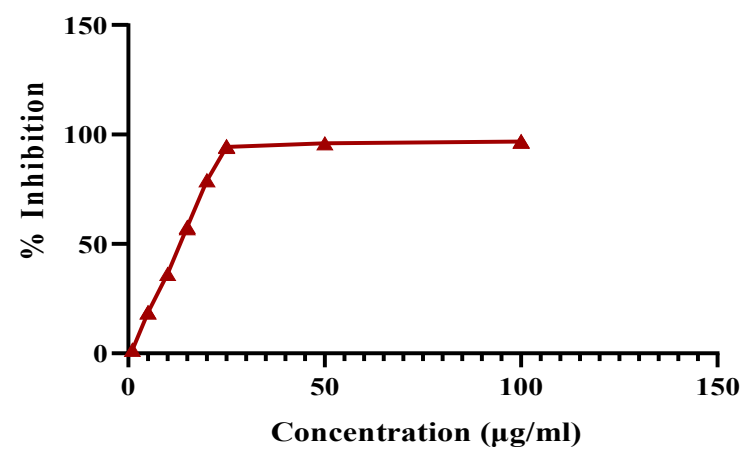

Fig. 2. Variation of \%inhibition against concentration of different extract and standard by DPPH assay. 
Table 7. Ferric reducing antioxidant power (FRAP) of the different seed extracts $P$. domestica and ascorbic acid (standard)

\begin{tabular}{lcc}
\hline Solvent/Extract & Ferric reducing antioxidant power $(\boldsymbol{\mu M} / \mathbf{m l})$ & FRAP value \\
\hline Ascorbic acid (standard) & $472.601 \pm 0.140$ & $2.000 \pm 0.000$ \\
\hline Petroleum ether & $20.341 \pm 0.645$ & $0.180 \pm 0.001$ \\
\hline Diethyl ether & $56.032 \pm 0.985$ & $0.325 \pm 0.002$ \\
\hline Ethyl acetate & $18.634 \pm 0.243$ & $0.173 \pm 0.002$ \\
\hline Methanol & $15.788 \pm 0.745$ & $0.162 \pm 0.001$ \\
\hline Aqueous & $14.731 \pm 0.879$ & $0.155 \pm 0.002$
\end{tabular}

Each experiment was performed in triplicate. All the values are represented as the mean \pm SD.

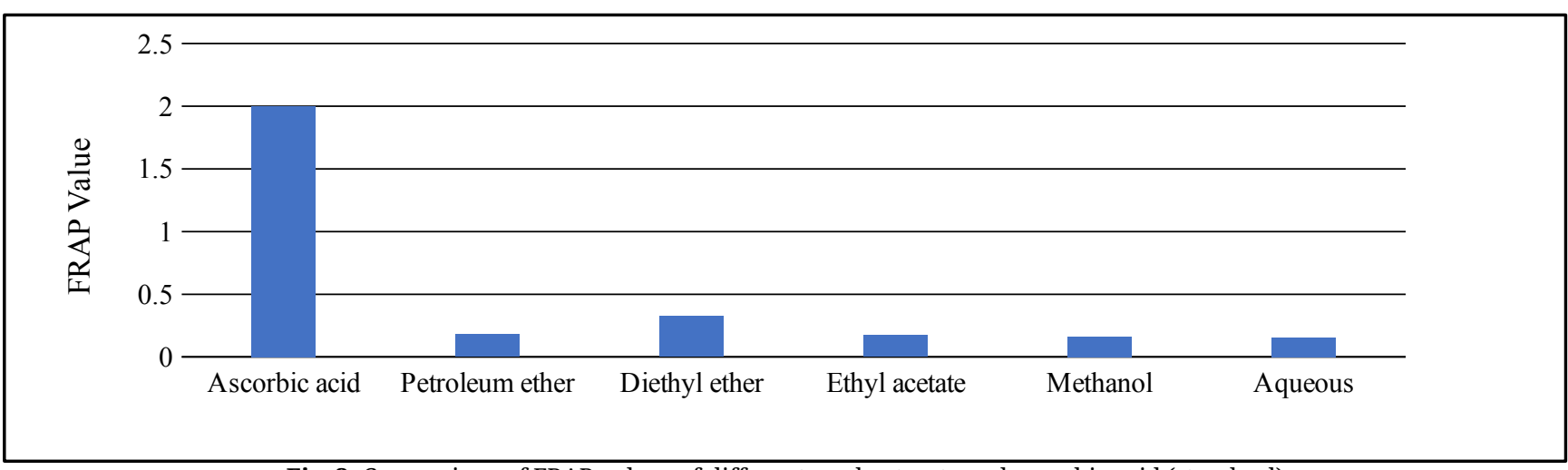

Fig. 3. Comparison of FRAP values of different seed extracts and ascorbic acid (standard).

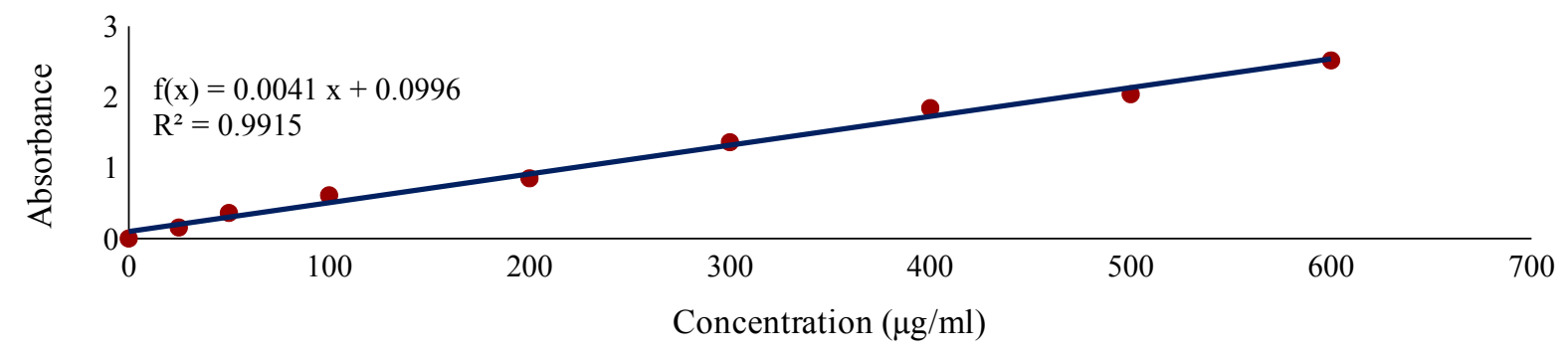

Fig. 4. Calibration curve of ascorbic acid.

\section{Acknowledgements}

Author $\mathrm{K}$ is thankful to the Council of Scientific and Industrial Research (CSIR), PUSA, New Delhi, India for providing the Junior research fellowship (JRF).

\section{Authors' contributions}

Concept and planning of the work was supervised by RKS and AS. Experimental work related to the physical parameters, proximate analysis, nutritive value, preliminary phytochemical screening, total phenolic content and antioxidant activity was done by $\mathrm{K}$. RS with $\mathrm{K}$ has participated in the design and study of the antioxidant activity. Manuscript writing and statistical calculations were done the $\mathrm{K}$. Corrections in the final manuscript were also done by $K$. All the authors have read the manuscript and given their approval for the final manuscript.

\section{Conflict of interests}

Authors do not have any conflict of interests to declare.

\section{References}

1. Asraf CM, Iqbal S, Ahmed D. Nutritional and physicochemical studies on fruit pulp, seed and shell of indigenous Prunus persica. Journal of Medicinal Plants Research. 2011; 5(16):391721.

2. Mehta S, Soni N, Satpathy G, Gupta RK. Evaluation of nutritional phytochemical, antioxidant and antibacterial activity of dried plum (Prunus domestica). Journal of Pharmacognosy and Phytochemistry. 2014;2(2):166-71.

3. Mahmood A, Ahmed R, Kosar S. Phytochemical screening and biological activities of the oil components of Prunus domestica Linn. Journal of Saudi Chemical Society. 2009;13:273-77. https://doi.org/10.1016/j.jscs.2009.10.008

4. Hummer KE, Janick J. Rosaceae: taxonomy economic importance, genomics. In: Genetics and genomics of Rosaceae. Springer, New York, NY; $2009 . \quad$ p.1-17. https://doi.org/10.1007/978-0-387-77491-6_1

5. Zhang SD, Jin JJ, Chen SY, Chase MW, Soltis DE, Li H, Yang JB, Li DZ, Yi TS. Diversification of Rosaceae since the Late Cretaceous based on plastid phylogenomics. New Phytologist. 2017;214: 1355-67. https://doi.org/10.1111/nph.14461

6. Xiang Y, Huang CH, Hu Y, Wen J, Li S, Yi T, Chen H, Xiang J, Ma $\mathrm{H}$. Evolution of Rosaceae fruit types based on nuclear phylogeny in the context of geological times and genome duplication. Molecular Biology and Evolution. 2016;34(2):26281. https://doi.org/10.1093/molbev/msw242

7. Gilani, SA, Qureshi RA, Khan AM, Potter D. Morphological characterization of the pollens of the selected species of genus 
Prunus Linn. from northern Pakistan. African Journal of Biotechnology. 2010;9(20):2872-79.

8. Vicente AR, Manganaris GA, Zevallos LC, Crisosto CH. 13 Prunus. Health-promoting properties of fruits and vegetables (ed. Terry LA). CAB International; 2011. p.238-59. https://doi.org/10.1079/9781845935283.0238

9. Das B, Ahmed N, Singh P. Prunus diversity- early and present development: A review. International Journal of Biodiversity and Conservation. 2011;3(14):721-34. https://doi.org/10.5897/IJBCX11.003

10. Khallouki F, Haubner R, Erben G, Ulrich CM, Owen RW. Phytochemical composition and antioxidant capacity of various botanical parts of the fruits of Prunus X domestica L. from the Lorraine region of Europe. Food Chemistry. 2012; 133:697-706. https://doi.org/10.1016/j.foodchem.2012.01.071

11. Chiej R. McDonald Encyclopaedia of Medicinal Plants. Macdonald and Co (Publisher) Ltd; 1984.

12. Ionica ME, Nour V, Trendafir I, Cosmulescu S, Botu M. Physical and chemical properties of some european plum cultivars (Prunus domestica L.). Notulae Botanicae Horti Agrobotanici Cluj-Napoca. 2013;41(2):499-503. https://doi.org/10.15835/nbha4129354

13. Kikuzaki H, Kayano S, Fukutsuka N, Aoki A, Kasamatsu K, Yamasaki Y, Mitani T, Nakatani N. Abscisic acid related compounds and lignans in Prunus (Prunus domestica L.) and their oxygen radical absorbance capacity (ORAC). Journal of Agricultural and Food Chemistry. 2004;52(2):344-49. https://doi.org/10.1021/jf034954v

14. Baranowski R, Kabut J, Baranowska I. Analysis of Mixture of catechins, flavones, flavanones, flavonoids and anthocyanidin by RP-HPLC. Analytical Letter. 2004;37(1):157-65. https://doi.org/10.1081/AL-120027781

15. Nagarajan GR, Seshadri TR. Flavonoid components of the heartwood of Prunus domestica Linn. Phytochemistry. 1964 3(4): 477-84. https://doi.org/10.1016/S0031-9422(00)88024-3

16. Bose M, Kamra M, Mullick R, Bhattacharya S, Das S, Karande AA. Identification of a flavonoid isolated from plum (Prunus domestica) as a potent inhibitor of hepatitis C virus entry. $\begin{array}{lll}\text { Scientific } & \text { Reports. } & \text { 2017;7(1):1-11. }\end{array}$ https://doi.org/10.1038/s41598-017-04358-5

17. Kayano S, Kikuzaki H, Ikami T, Suzuki T, Mitani T, Nakatani N A new bipyrrole and some phenolic constituents in prunes (Prunus domestica L.) and their oxygen radical absorbance capacity (ORAC). Bioscience Biotechnology and Biochemistry. 2004;68(4):942-44. https://doi.org/10.1271/bbb.68.942

18. Virinder S, Jain R. Dihydroflavonol from Prunus domestica. Phytochemistry. https://doi.org/10.1016/0031-9422(92)80399-Y

19. Dikeman CL, Bauer LL, Fahey GC. Carbohydrate composition of selected plum/prune preparations. Journal of Agriculture and Food Chemistry. 2004;52:853-59. https://doi.org/10.1021/jf034858u

20. Singh Z, Khan A. Stewart postharvest review. 2010;6(2):1-10. https://doi.org/10.2212/spr.2010.2.3

21. Usenik V, Stampar F, Kastelec D. Phytochemicals in fruits of two Prunus domestica L. plum cultivars during ripening.
Journal of the Science of Food and Agriculture. 2012;93(3): 68192. https://doi.org/10.1002/jsfa.5783

22. Jabeen Q, Aslam N. The pharmacological activities of prunes: The dried plums. Journal of Medicinal Plants Research 2011;5(9):1508-11.

23. Nayudu TS, Sowjanya K. Anti-Diabetic activity of methanolic extract of Prunus domestica. International Journal on Recen and Innovation Trends in Computing and Communication. 2017;5(4):213-20

24. Indian pharmacopoeia. The Indian pharmacopoeia commission. Ministry of Health and Family Welfare, Ghaziabad: India; 2007.

25. Shukla RK, Nandan K, Shukla A, Kaur A. Phytochemical analysis and nutritive value of Bombax ceiba Linn. (Petals) Plant Archives. 2020; 20(1):1201-06.

26. Harborne JB. Phytochemical Methods; A Guide to Modern Techniques of Plant Analysis. Chapman and Hall Co., NewYork; 1998. p.1-198

27. Kokate, CK, Purohit AP, Gokhle SB. Pharmacognosy, $35^{\text {th }}$ ed. Nirali Prakashan: India; 2006. p. 593-97.

28. Waterhouse AL. Determination of total phenolics. In Worlstand RE Ed. Current Protocols in Food and Analytical Chemistry. 2002 https://doi.org/10.1002/0471142913.faa0101s06

29. Brand-William W, Cuvielier ME, Berset C. Use of free radical method to evaluate antioxidant activity. LWT- Food Science and Technology. 1995; 28: 25-30. https://doi.org/10.1016/S00236438(95)80008-5

30. Benzie FF, Strain JJ. Ferric reducing/ antioxidant power assay: direct measure of total antioxidant activity of biological fluids and modified version for simultaneous measurement of total antioxidant power and ascorbic acid concentration. Methods in Enzymology. 1999;299:15-23. https://doi.org/10.1016/S00766879(99)99005-5

Additional information

Peer review information: Plant Science Today thanks Sectional Editor and the other anonymous reviewers for their contribution to the peer review of this work.

Reprints and permissions information is available at https://horizonepublishing.com/journals/index.php/PST/open_access_policy

Publisher's Note: Horizon e-Publishing Group remains neutral with regard to jurisdictional claims in published maps and institutional affiliations.

To cite this article: Shukla R K, Kishan, Shukla A, Singh R. Evaluation of nutritive value, phytochemical screening, total phenolic content and in-vitro antioxidant activity of the seed of Prunus domestica L.. Plant Science Today. 2021;8(4):830 835. https://doi.org/10.14719/pst.2021.8.4.1231

Plant Science Today, published by Horizon e-Publishing Group, is covered by Scopus, Web of Science, BIOSIS Previews, Clarivate Analytics, etc. See https://horizonepublishing.com/journals/index.php/PST/indexing_abstracting 